\title{
SHEPHERD'S COTTAGE, SUFFOLK
}

Jeanette Miller

The old woman who died here

three years ago

didn't, for a lifetime, go

beyond the road

where the red-mantled pheasants

strut ahead of their mates

into the nettle.

She walked the hill

(where adders sleep)

in high, black boots,

whistling and singing,

walked the narrow stairs,

a bowl of water in her hands,

mirrored in rain. Her window-

rows of pines planted to the sea.

A breakfast of sausages, fried bread, tomatoes.

A thread of steam rises from my cup, disappearing into a poster of the Heathland.

Dwarf gorse, bristle bent, bell heather.

Did she take the yellow-flowered broom for granted?

Sand road. The bleached carcass of a squirrel.

Blackberries.

Blue phlox, dark whorls at their centers. 
A carved, wooden angel

hangs above the bed

where she slept alone,

wrapped in eiderdown,

while the nights of solitude

repeated themselves with certainty

like the stitches that tie together

the layers of the quilt,

binding its edges. 